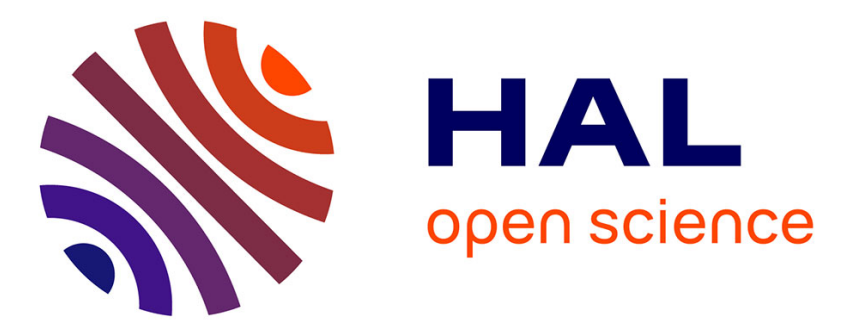

\title{
Carbon monoxide poisoning from waterpipe (narghile) smoking in a child
}

\author{
N. de Suremain, J. Ngo, S. Loschi, I. Haegy-Doehring, J. Aroulandom, R. \\ Carbajal
}

\section{- To cite this version:}

N. de Suremain, J. Ngo, S. Loschi, I. Haegy-Doehring, J. Aroulandom, et al.. Carbon monoxide poisoning from waterpipe (narghile) smoking in a child. Archives de Pédiatrie, 2019, 26, pp.44 - 47. 10.1016/j.arcped.2018.11.008 . hal-03486156

\section{HAL Id: hal-03486156 https://hal.science/hal-03486156}

Submitted on 20 Dec 2021

HAL is a multi-disciplinary open access archive for the deposit and dissemination of scientific research documents, whether they are published or not. The documents may come from teaching and research institutions in France or abroad, or from public or private research centers.
L'archive ouverte pluridisciplinaire HAL, est destinée au dépôt et à la diffusion de documents scientifiques de niveau recherche, publiés ou non, émanant des établissements d'enseignement et de recherche français ou étrangers, des laboratoires publics ou privés.

\section{(ㄷ)(1) $\$$}

Distributed under a Creative Commons Attribution - NonCommercial| 4.0 International 
Carbon monoxide poisoning from waterpipe (narghile) smoking in a child Short title: Carbon monoxide poisoning from waterpipe smoking

N. de Suremain ${ }^{1 *}$, J. Ngo $^{2}, \mathrm{~S}_{\text {L Loschi }}{ }^{1}$, I. Haegy-Doehring ${ }^{3}$, J. Aroulandom ${ }^{1}$, R. Carbajal ${ }^{1,4}$

1 Service des urgences pédiatriques, Hôpital Armand Trousseau, AP-HP, 75012 Paris, France

2 Service de médecine de la douleur, Hôpital Armand Trousseau, AP-HP, 75012 Paris, France

3 Service de réanimation, Hôpital Raymond Poincaré, AP-HP, 92380 Garches, France 4 Inserm U1153, Université Pierre et Marie Curie, Sorbonne universités, Paris VI, 75005 Paris, France

*Corresponding author : Dr Nathalie de Suremain, Service des urgences pédiatriques, Hôpital Armand Trousseau, AP-HP, 26 Avenue du Dr Arnold Netter, 75012 Paris, France. Email : nathalie.desuremain@aphp.fr

Poste 0171738449

Acknowledgments : Les auteurs remercient tous les membres des urgences pédiatriques de l'hôpital Trousseau

\title{
Conflicts of interest : None
}

\begin{abstract}
:
Shisha smoking has spread to many countries since the 1990s and is now a global phenomenon among adolescents. Notwithstanding the connotations of conviviality of shisha smoking, it is in fact highly dangerous since the smoke inhaled contains toxic substances. Carbon monoxide (CO) poisoning carries a high risk of neurological and neuropsychological sequelae such as memory loss, impaired concentration, mood disorders, and various other symptoms. We report a case of severe $\mathrm{CO}$ poisoning in a 13year-old boy after smoking shisha that caused loss of consciousness and seizure. To our knowledge, there have as yet been no reports of cases involving children. We present some epidemiological data on shisha smoking in adolescents as well as on CO intoxication.

Keywords: CO, shisha, waterpipe, narghile, smoking, tobacco, adolescent, child.
\end{abstract}




\section{Introduction}

Shisha smoking (also termed narghile, shisha, or hookah) is becoming increasingly widespread in France, particularly among young people [1, 2]. It involves an oriental pipe composed of a water basin attached to a long flexible tube through which tobacco smoke is inhaled (Figure 1). According to popular belief, shisha smoking is less harmful and less addictive than cigarette smoking [3]. But shisha, notwithstanding its connotations of conviviality and exoticism, is in fact highly dangerous since the smoke inhaled during a shisha session contains numerous toxic substances such as polycyclic aromatic hydrocarbons, volatile aldehydes, carbon monoxide (CO), and nicotine [4]. In addition to the risk of dependence associated with regular smoking, even occasional inhalation may result in serious consequences. We report a case of severe $\mathrm{CO}$ poisoning in an adolescent after shisha smoking.

\section{Case Report}

A 13-year-old boy presented to the pediatric emergency department at $5 \mathrm{p}$.m. with a wound to his chin after losing consciousness when walking with a friend. He reported an episode of dizziness lasting around $10 \mathrm{~s}$ at approximately $4 \mathrm{p} . \mathrm{m}$. the same day after which he lost consciousness, injuring his chin as he fell. He regained consciousness within approximately 5 s. There was no urinary incontinence or tongue biting. He had made his own way to the emergency department. On arrival, he was conscious, afebrile, and exhibited normal behavior. At nurse triage, vital signs revealed a heart rate of 94 beats/minute, oxygen saturation of $98 \%$, and blood pressure of 116/60 mmHg. Capillary blood glucose was $6.3 \mathrm{mmol} / \mathrm{l}$. Twenty minutes after arrival to the emergency department, and before he had been examined by a physician, loss of consciousness recurred with tonic clonic movements of the upper limbs. The post-ictal phase lasted for 5 min before he regained consciousness. At that point, he 
disclosed that he had suffered from an episode resembling vasovagal syncope 2 years previously. A clinical examination, including neurological assessment, was normal. The patient's pupils were normal and reactive. There were no signs of pyramidal irritation. Deep tendon reflexes were normal. Blood gas was analyzed at 6 p.m. and revealed $\mathrm{CO}$ poisoning with a carboxyhemoglobin $(\mathrm{COHb})$ level of $23.1 \%$. A non-rebreather high-dose oxygen mask at atmospheric pressure was fitted pending transfer to a specialized center for hyperbaric oxygen therapy. Electrocardiographic findings were normal and the lactate level was 2.3 $\mathrm{mmol} / \mathrm{l}$. The patient received one session of hyperbaric oxygen therapy in a pressure chamber. The favorable development of his condition allowed him to return home the next day. At the follow-up 1 month later, an electroencephalogram was normal.

Observation of high carboxyhemoglobin levels led to further questioning, which revealed that he was an occasional cigarette and shisha smoker; he disclosed that he had recently smoked shisha and said that he had done that at a friend's house in the basement the night before. However, despite our questioning, the patient did not give any details regarding the duration of the session or its frequency, undoubtedly because of the presence and disapproving attitude of his mother. Since the adolescent retracted his initial confession, the family did not accept the proposal of a follow-up consultation related to the risks of tobacco and shisha consumption.

We declared the intoxication to local authorities. According to the findings of a public health toxicology investigation launched by the authorities of the City of Paris, there were no other sources of $\mathrm{CO}$ at the patient's home or within his social circle.

\section{Discussion}

This case report describes severe $\mathrm{CO}$ poisoning in a 13-year-old boy after smoking shisha, causing loss of consciousness and seizure. Although this episode resulted in a satisfactory outcome, thanks to the normobaric and then hyperbaric oxygen therapy, it is important to 
emphasize that $\mathrm{CO}$ poisoning is far from harmless and carries a high risk of neurological and neuropsychological sequelae such as memory loss, impaired concentration, mood disorders, and various other symptoms very likely arising from inflammatory events [5].

Pediatric and adult symptoms of CO poisoning may differ. In a series of 28 pediatric patients, Croker and Walter found that all patients with a $\mathrm{COHb}$ above $15 \%$ were symptomatic; high incidences of syncope (56\%) and lethargy (68\%) were observed [6].

Since 2009, several reviews have reported isolated cases of CO poisoning in adults after smoking shisha; these cases were summarized in 2017 by Eichhorn et al., who listed a total of 42 [4]. These authors also reported a retrospective cohort study conducted at a hyperbaric oxygen therapy referral center in Germany [4]. Between January 2013 and December 2016, 61 patients were identified as having $\mathrm{CO}$ poisoning after smoking shisha. The mean $\mathrm{COHb}$ level in this cohort was $26.9 \%$ and the most common symptoms were loss of consciousness, dizziness, headaches, and nausea [4]. No obvious correlation was observed between symptoms and $\mathrm{COHb}$ levels. Nevertheless, loss of consciousness occurred in over $75 \%$ of patients with $\mathrm{COHb}$ levels ranging from $16 \%$ to $30 \%$ and in all three patients whose $\mathrm{COHb}$ levels exceeded $30 \%$ [4]. Although this retrospective study included patients aged 13 years or older, to our knowledge, to date, there have no reports of shisha-related $\mathrm{CO}$ poisoning specifically involving children.

Shisha smoking has been a tradition in India, Africa, and Asia for over four centuries [7]. It has spread widely to other countries since the 1990s and is now a global phenomenon among not only young adults but also adolescents [7]. Shisha is increasingly consumed in the United States and Europe both at home and in bars. A study conducted on students from 152 universities in the United States during 2008-2009 demonstrated that 30.5\% of the students had previously smoked shisha and $8.4 \%$ had done so within the previous 30 days [8]. In France, shisha bars/oriental tea rooms are flourishing [9]. Shisha is a very fashionable means 
of smoking tobacco among adolescents who see it as a fun and friendly way of meeting up with friends [10]. A survey carried out in France (European School Survey Project on Alcohol and Other Drugs) in 2015 among 6,642 college students with a mean age of 17.1 years found that $48 \%$ had previously smoked shisha [1]. It is noteworthy that in a similar survey in 2011, $61 \%$ had experimented with shisha [1]. The shisha trend has spread to school students; the Health Behavior in School-aged Children (HBSC) survey carried out in France in 2014 among school students aged between 11 and 15 years revealed that $17.2 \%$ had already smoked shisha [2]. Another French survey on patterns of shisha consumption in 2007 among young people with a mean age of 21.2 years demonstrated that consumption occurred as a rule on an occasional basis, with $60 \%$ ranging from once a week to once a month, most frequently in the evening $(87 \%)$ or at the weekend $(84 \%)$ [10]. The median length of sessions ranged from 40 to $49 \min [10]$.

The most commonly used shisha tobacco, referred to as moassel, is made up of $30 \%$ tobacco and $70 \%$ molasses flavored with fruit or various essences [11]. Manufacturers vie with each other to invent new flavors and entice these young customers. The sweetness and fruity flavors of the tobacco are appealing and create the impression that it is less harmful than cigarette tobacco, thus largely underestimating its impact on the health of those who smoke it. According to one of the aforementioned French surveys, $22 \%$ of smokers consider shisha to be nontoxic and only $10 \%$ of users intend to stop smoking [10]. And yet it is indisputably a toxic substance. Primack et al. in 2016 reported a systematic review and meta-analysis comparing the harmful effects of shisha and cigarette consumption [12]. Across 17 studies, they found that in a typical shisha session, 74.11 of smoke was inhaled compared with 0.61 for one cigarette, meaning that 125 times more smoke is inhaled in a shisha session than when smoking a cigarette [12]. A comparison of the inhalation of other toxic substances in a shisha session versus a single cigarette yielded the following results: nicotine, $4.1 \mathrm{mg}$ versus $1.8 \mathrm{mg}$; 
tar, $619.0 \mathrm{mg}$ versus $24.5 \mathrm{mg}$; and CO, $192.0 \mathrm{mg}$ versus $17.7 \mathrm{mg}$ [12]. Thus, even if moassel tobacco contains less nicotine than cigarette tobacco, one shisha session delivers as much nicotine as approximately three cigarettes $[11,12]$. Where CO is concerned, $90 \%$ of its high levels of production originate in the combustion of the charcoal used to heat the tobacco [13]. Moreover, self-lighting charcoal, which is used twice as much as natural coal [10], emits more $\mathrm{CO}$ and toxic substances, making it less safe than standard coal [9]. A study including volunteers with a mean age of 26 years demonstrated that shisha inhalation spanning 30 min caused a rise in $\mathrm{COHb}$ levels from a baseline level of $1.3 \%$ to $23.7 \%$ and induced electrocardiographic changes such as QT and P-wave dispersion [14]. Furthermore, the substances used to flavor shisha tobacco may exert negative health effects, which are as yet little known. From our point of view, awareness of the epidemiology of shisha consumption in young people and the risk they run of $\mathrm{CO}$ poisoning should prompt the emergency physicians who treat these patients to evoke this type of poisoning as a potential diagnosis in the event of nonspecific neurological symptoms.

Approximately a quarter of consumers smoke in shisha bars [10]. CO concentration in these bars may rise to 4-8 times higher than the alert threshold for urban air pollution $[9,15]$. Mean $\mathrm{PM}_{2,5}$ particle concentrations can reach $515 \mu \mathrm{g} / \mathrm{m}^{3}$ [15], whereas the World Health Organization recommends that urban air should not exceed $25 \mu \mathrm{g} / \mathrm{m}^{3}$. A study on levels of CO inside shisha bars conducted in Paris in 2007 indicated wide variability proportionate to time of day, number of customers present, and ventilation of premises [16]. As in cigarette smoking, shisha is a source of pollution for both smokers and other customers present in the bar since $1 \mathrm{~h}$ spent in a shisha bar without smoking amounts to the equivalent of smoking six or seven cigarettes in terms of $\mathrm{CO}$ [16]. There has been evidence of passive poisoning in a nonsmoking member of bar staff necessitating treatment of $\mathrm{CO}$ poisoning by hyperbaric oxygen therapy [17]. 
Lastly, in shisha bars, mouthpieces are rarely changed from one user to another, as illustrated by a survey conducted among young people: In $80 \%$ of cases, mouthpieces were shared without taking any precautions [10]. There is therefore a risk of transmission of diseases such as tuberculosis [11].

Treatment of shisha $\mathrm{CO}$ poisoning is similar to that of other causes of $\mathrm{CO}$ poisoning. Despite a certain degree of controversy surrounding its use to this day, the Undersea and Hyperbaric Medical Society recommends hyperbaric oxygen therapy in $\mathrm{CO}$ poisoning [5]. In a randomized study involving adults, it was shown that hyperbaric oxygen therapy reduced the incidence of cognitive sequelae at 6 weeks $(46 \%)$ by comparison with normobaric oxygen therapy $(25 \%)$ [18]. Certain experts recommend hyperbaric oxygen therapy for all patients having undergone severe poisoning involving loss of consciousness, cardiac ischemia alterations, neurological deficits, metabolic acidosis, or COHb levels greater than 25\% [19]. Normobaric oxygen therapy reduces $\mathrm{CO}$ elimination half-life from $320 \mathrm{~min}$ in ambient air to $74 \mathrm{~min}$, whereas hyperbaric oxygen therapy reduces the same half-life to $20 \mathrm{~min}$ [19]. These data on half-life pertain to trials involving adults; data on children and young adolescents are insufficient. However, the literature shows that exposed children often become symptomatic earlier, and recover faster, than similarly exposed adults, because of their lower blood volume and increased minute ventilation per unit of body mass as compared with adults [5].

Since the trend toward increased shisha consumption is global, the World Health Organization has issued a warning against the serious health risks of shisha smoking for users and those who accompany them [7]. It recommends the same kind of regulatory measures as those adopted for other forms of tobacco, information for users of the risks involved, and prohibition of any slogan or advertisement implying that shisha smoking is harmless [7]. Also, as for any other type of $\mathrm{CO}$ poisoning, these $\mathrm{CO}$ intoxications should be notified to 
local authorities. In France, they are notified to the "Centre Anti Poison," the Central Laboratory of the "Prefecture de Police" for Paris, and the "Agence Regional de Santé" for all other regions.

\section{Conclusion}

Shisha smoking should not be trivialized. Surveys have demonstrated that it is very popular among adolescents, including younger adolescents who for the most part are unaware of the risks involved. The risks of $\mathrm{CO}$ poisoning are related firstly to high levels of $\mathrm{CO}$ in shisha smoke, which are much more substantial than those contained in cigarettes, and secondly to poor ventilation on the premises used for smoking. It is of utmost importance to ensure that public information campaigns are organized to warn young people against these understated health hazards. 


\section{References}

1. Le Nezet $\mathrm{O}$, Ngantcha $\mathrm{M}$, Beck F,et al. La consommation de tabac au cours des années lycée. Résultats de l'enquête ESPAD 2015, 2016, Bulletin Epidémiologique Hebdomadaire. 30-31. p. 515-21. http://invs.santepubliquefrance.fr/beh/2016/3031/pdf/2016 30-31 5.pdf

2. Spilka S, Ehlinger V, Le Nézet O, et al. Alcool, tabac et cannabis en 2014, durant les années collège. Tendances, OFDT, 2015. $\mathrm{N}^{\circ}$ 106; décembre: p. 1-5. https://www.ofdt.fr/publications/collections/periodiques/lettre-tendances/alcool-tabacet-cannabis-en-2014-durant-les-annees-college-tendances-106-decembre-2015/.

3. Smith-Simone S, Maziak W, Ward KD, et al. Waterpipe tobacco smoking: knowledge, attitudes, beliefs, and behavior in two U.S. samples. Nicotine Tob Res 2008;10:393-8.

4. Eichhorn L, Michaelis D, Kemmerer M, et al. Carbon monoxide poisoning from waterpipe smoking: a retrospective cohort study. Clin Toxicol (Phila) 2018; 56: 26472

5. $\quad$ Weaver LK. Clinical practice. Carbon monoxide poisoning. N Engl J Med 2009; 360:1217-25.

6. Crocker PJ, Walker JS. Pediatric carbon monoxide toxicity. J Emerg Med 1985;3:4438.

7. World Health Organization, TobReg advisory note: waterpipe tobacco smoking: health effects, research needs and recommended actions by regulators. Geneva, WHO, 2005.

8. Primack BA, Shensa A, Kim KH, et al. Waterpipe smoking among U.S. university students. Nicotine Tob Res 2013;15:29-35.

9. Dautzenberg B, Nau JY. Tout ce que vous ne savez pas sur la chicha. Paris, Margaux Orange, OFT, 2007, 144p.

10. Dautzenberg B, Bertholon JF, Becquemin MH. Enquête sur le mode de consommation de la chicha (narguilé) en 2007 en France. Bull Epidémiol Heb 2007 ;21:183

11. Knishkowy B, Amitai Y. Water-pipe (narghile) smoking: an emerging health risk behavior. Pediatrics 2005;116: e113-9.

12. Primack BA, Carroll MV, Weiss PM, et al. Systematic Review and Meta-Analysis of Inhaled Toxicants from Waterpipe and Cigarette Smoking. Public Health Rep 2016;131:76-85.

13. Monzer B, Sepetdjian E, Saliba N, et al. Charcoal emissions as a source of CO and carcinogenic PAH in mainstream narghile waterpipe smoke. Food Chem Toxicol 2008;46:2991-5.

14. Yildirim F, Çevik Y, Emektar E, et al. Evaluating ECG and carboxyhemoglobin changes due to smoking narghile. Inhal Toxicol 2016;28: 546-9.

15. Travers MJ, Kulak JA, Vogl L. Waterpipe cafes are hazardous to your health: Determination of a waterpipe specific calibration factor. Int J Hyg Environ Health 2018;221:48-53.

16. Dahech $\mathrm{S}$, Beltrando G. Le taux de $\mathrm{CO}$ dans les bars à chicha : étude de cas à Paris en fonction de la consommation et de la ventilation des locaux. JIQA 2008. 7-8 Février 2008 http://www.jiqa.fr/doc/2008/Article/DAHECH.pdf.

17. Levant A, Cabot $\mathrm{C}$, Genestal $\mathrm{M}$, et al. Intoxication aiguë au $\mathrm{CO}$ par narguilé. Le Courrier des addictions, 2007. $\mathrm{n}^{\circ} 3$ (juillet-août-septembre 2007): http://www.edimark.fr/Front/frontpost/getfiles/13405.pdf.

18. Weaver LK, Hopkins RO, Chan KJ, et al. Hyperbaric oxygen for acute carbon monoxide poisoning. N Engl J Med 2002;347:1057-67. 
19. Rose JJ, Wang L, Xu Q, et al. Carbon Monoxide Poisoning: Pathogenesis, Management, and Future Directions of Therapy. Am J Respir Crit Care Med 2017;195: 596-606.

Figure

Figure 1 : Description of the waterpipe

The head has a container that holds the coal and tobacco during the smoking session. The coal is placed above the tobacco from which it is separated by perforated aluminum foil.

Holes in the bottom of the head allow smoke to pass into the body's central conduit. This conduit is submerged in the water that half-fills the water base.

The hose exits from the water base top and ends with a mouthpiece from which the smoker inhales.

The dotted line shows the path of the inhaled smoke, which contains charcoal and tobacco combustion products. 


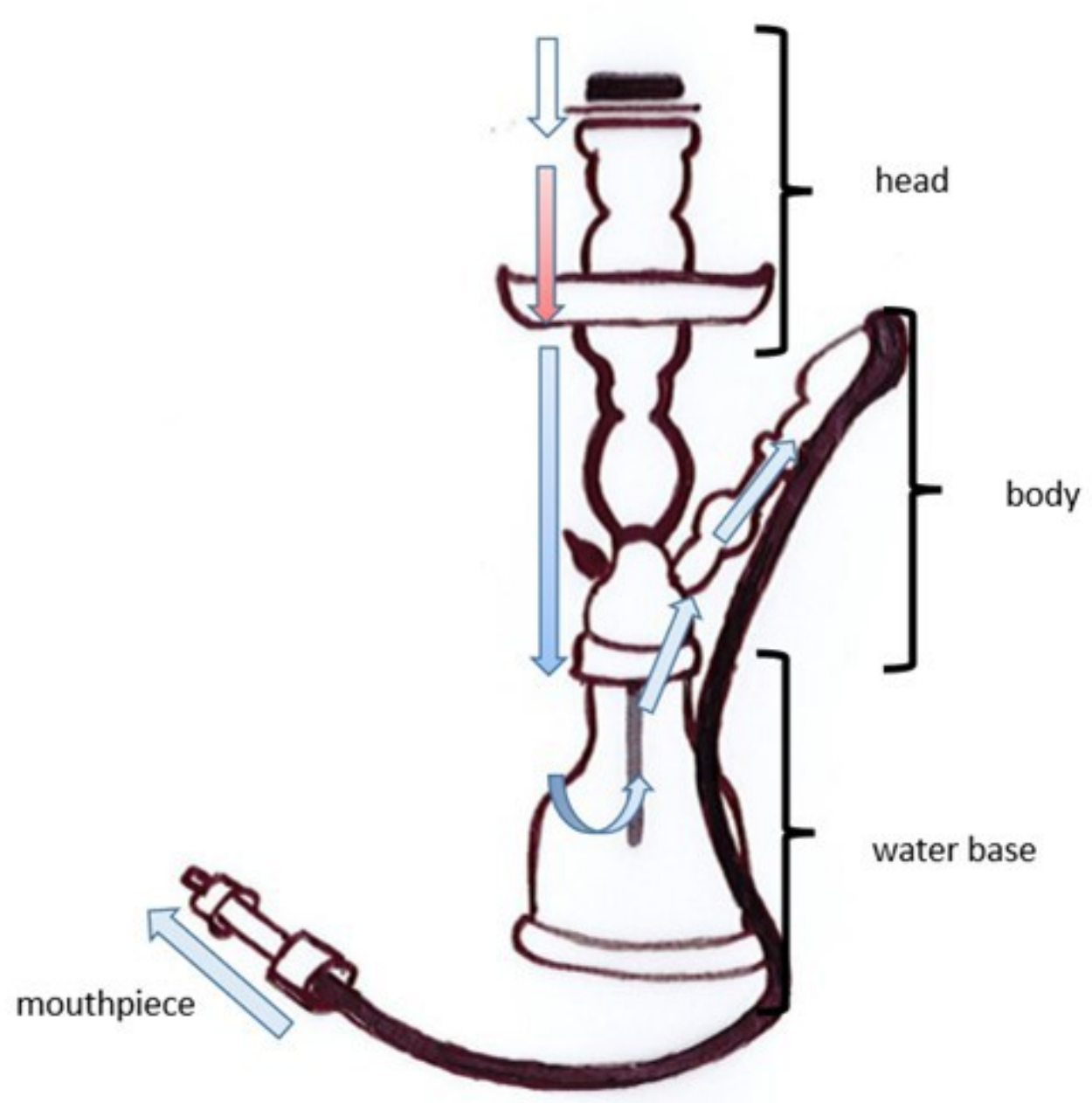

hose 